\title{
The Role of Vitamin D Deficiency in the Incidence, Progression, and Complications of Type 1 Diabetes Mellitus
}

\author{
Marlene Chakhtoura and Sami T. Azar \\ Department of Internal Medicine, Division of Endocrinology and Metabolism, American University of Beirut-Medical Center, \\ 3 Dag Hammarskjold Plaza, 8th floor, New York, NY 10017, USA
}

Correspondence should be addressed to Sami T. Azar; sazar@aub.edu.lb

Received 19 November 2012; Revised 23 January 2013; Accepted 29 January 2013

Academic Editor: Guang-Da Xiang

Copyright (C) 2013 M. Chakhtoura and S. T. Azar. This is an open access article distributed under the Creative Commons Attribution License, which permits unrestricted use, distribution, and reproduction in any medium, provided the original work is properly cited.

\begin{abstract}
The "nonclassic" role of 1,25-dihydroxyvitamin D3 $\left(1,25(\mathrm{OH})_{2} \mathrm{D}_{3}\right)$ has been recently widely recognized. In type 1 diabetes mellitus (T1D), it plays an immunomodulatory role through the vitamin D receptor (VDR) present on pancreatic and immune cells. Specific VDR allelic variants have been associated with T1D in many countries. Furthermore, vitamin D deficiency has been prevalent in T1D, and the seasonal and latitude variability in the incidence of T1D can be partly explained by the related variability in vitamin $\mathrm{D}$ level. In fact, retrospective studies of vitamin D supplementation during pregnancy or infancy showed a lower incidence of T1D. We will review the different mechanisms of the vitamin D protective effect against insulitis and present the available data on the role of vitamin D deficiency in the control, progression, and complications of T1D.
\end{abstract}

\section{Introduction}

Type 1 diabetes (T1DM) is an autoimmune disease occurring in the pancreatic islets [1]. It accounts for $90 \%$ of diabetes in children and adolescents [2]. Its incidence varies considerably worldwide, being highest in Finland and Sardinia [3], probably related to genetic, dietary, and environmental factors that might interfere with its pathogenesis [4]. The annual incidence has been increasing worldwide, possibly related to higher socioeconomic status and degree of urbanization [5]. Recently, there has been appealing evidence on the "nonclassic" role of vitamin D in many autoimmune diseases including rheumatoid arthritis, scleroderma, psoriasis, multiple sclerosis, and also T1DM [6, 7]. In fact, in addition to its skeletal effects and control of calcium hemostasis, 1,25DihydroxyvitaminD3 $\left(1,25(\mathrm{OH})_{2} \mathrm{D}_{3}\right)$ showed potent antiproliferative and immunomodulatory properties [8].

In this paper, we will review the available data on the relationship between vitamin D and T1DM trying to elucidate the immunomodulatory mechanisms of vitamin $\mathrm{D}$ on pancreatic insulitis, seasonal and latitude effects, protective effects of supplements on T1DM incidence, complications and progression.

\section{Immunomodulatory Effect of Vitamin D}

$1,25(\mathrm{OH})_{2} \mathrm{D}_{3}$ plays an immunomodulatory role in the prevention of T1DM, through the vitamin $\mathrm{D}$ receptor (VDR) expressed in antigen presenting cells, activated T cells [9], and pancreatic islet $\beta$-cells [10]; this has been demonstrated in many trials done on nonobese diabetic mice (NOD) - a murine model of human IDDM, spontaneously developing diabetes mellitus (DM) - using $1,25(\mathrm{OH})_{2} \mathrm{D}_{3}$ or its analogue $\left(1,25(\mathrm{OH})_{2} \mathrm{D}_{3}, \mathrm{MC1} 288\left(20\right.\right.$-epi-1,25(OH) $\left.{ }_{2} \mathrm{D}_{3}\right)$, or KH1060 $\left(1,25(\mathrm{OH})_{2}\right.$-20-epi-22-oxa-24,26,27,-trishomovitamin D) [9]. Conversely, $1,25(\mathrm{OH})_{2} \mathrm{D}_{3}$-deficient mice were at higher risk of developing $\mathrm{DM}$, with a more aggressive course when deficiency is present early in life $[11,12] .1,25(\mathrm{OH})_{2} \mathrm{D}_{3}$, administered early on, protects against or reduces the severity of pancreatic insulitis via a dual action, on the pancreatic beta cells and on the immune cells [13]. Furthermore, administration of $1,25(\mathrm{OH})_{2} \mathrm{D}_{3}$ in combination with cyclosporine $\mathrm{A}$, after the onset of the autoimmune attack, which is known as a prediabetic state, can prevent clinical diabetes [14].

At the level of the pancreatic islets, $1,25(\mathrm{OH})_{2} \mathrm{D}_{3}$ decreased in vivo and in vitro proinflammatory chemokine and cytokine expression (e.g., IL6), which are implicated in 




Figure 1

the pathogenesis of T1DM making $\beta$-cells less chemoattractive and less prone to inflammation; this results in decreased T cell recruitment and infiltration, increased regulatory cells, and arrest of the autoimmune process [15-17]. Furthermore, $1,25(\mathrm{OH})_{2} \mathrm{D}_{3}$ decreases MHC class I expression leading to reduced vulnerability of islet $\beta$-cells to cytotoxic T lymphocytes [18].

At the level of the immune system, $1,25(\mathrm{OH})_{2} \mathrm{D}_{3}$ inhibits the differentiation and maturation of dendritic cells and promotes their apoptosis [19], preventing their transformation into antigen presenting cells which is the first step in the initiation of an immune response [20]. It has been also demonstrated that $1,25(\mathrm{OH})_{2} \mathrm{D}_{3}$ restores the suppressor cells, decreases Th1 cytokine production-responsible for $\beta$-cell death-and shifts the immune response toward Th2 pathway, leading to benign insulitis [21-24]. The addition of $1,25(\mathrm{OH})_{2} \mathrm{D}_{3}$ inhibits the production of Il-6, a direct stimulator of Th17 cells [19], implicated in many autoimmune diseases, including T1D [20]. On the other hand, $1,25(\mathrm{OH})_{2} \mathrm{D}_{3}$ exerts antiapoptotic effects on the cytokineinduced pancreatic $\beta$-cells apoptosis. It induces and maintains high levels of A20 gene protein, which leads to decreased nitric oxide (NO) levels. In fact, NO induces directly beta cell dysfunction and death, and, indirectly, through the induction of Fas expression [25]; Fas is a transmembrane cell surface receptor and a member of the tumor necrosis factor (TNF) receptor family. It is stimulated by inflammatory cytokines secreted by islet-infiltrating mononuclear cells. It renders the $\beta$-cells in T1DM susceptible to Fas-Ligand-induced apoptosis mediated by tissue-infiltrating Fas-Ligand-positive T lymphocytes [26]. Decreasing NO levels leads to down regulation of all the aforementioned mechanisms and allows cytoprotective effects on islet cells. In addition, $1,25(\mathrm{OH})_{2} \mathrm{D}_{3}$ has been found to be able to counteract the cytokine-induced Fas expression in human pancreatic islets, both at the mRNA and protein levels, modulating the cascade of death signals and preventing cell apoptosis [27] (Figure 1).

\section{Vitamin D Polymorphism}

Vitamin D and its analogues exert their actions through the nuclear VDR which is responsible for transducing the action of the active form of vitamin $\mathrm{D}, 1,25(\mathrm{OH})_{2} \mathrm{D}_{3}$ [28]. The VDR gene is located on chromosome 12q12-q14 in humans [29]. Polymorphisms within the VDR gene may be associated with altered gene expression or gene function [29], and many reports revealed their association with many physiologic and pathologic phenotypes, though inconsistently [30]. Five single nucleotide polymorphisms (SNP) in exon 2 (FokI), intron 8 (BsmI, Tru9I, ApaI), and exon 9 (TaqI) have been defined historically in VDR gene, by the associated restriction enzyme [31]. Association studies of VDR allelic variations and T1D done in many countries, including different populations (southern [32] and northern [33] India, Iran [34], Spain [35], Romania [36, 37], Turkey [38, 39], Hungary [40], Portugal [41], UK, US, Norway [42], Japan [42, 43], Finland [42, 44], Poland [45], Croatia [46, 47], Brazil [48], Uruguay [49], Germany [50-52], Greece [53], Bangladesh [54], Taiwan [55], 
TABLE 1: VDR gene polymorphism and type 1DM.

\begin{tabular}{|c|c|}
\hline Population & VDR polymorphism associated with IDDM \\
\hline Bangladesh & FokI, BsmI, ApaI, TaqI \\
\hline Brazil & No association \\
\hline Chile & BsmI, ApaI, Taq $\mathrm{I}^{1}$ \\
\hline Croatia & Tru91, Fok $\mathrm{I}^{2}$ \\
\hline Finland & No association \\
\hline Germany & $\operatorname{Tak\mathrm {I}}, A p a \mathrm{I}, B s m \mathrm{I}^{1}, \operatorname{Tr} u \mathrm{I}^{3}$ \\
\hline Greece & FokI, BsmI, ApaI, TaqI \\
\hline Hungary & BsmI, ApaI, Tru91 ${ }^{4}$ \\
\hline India Northern & FokI, TaqI \\
\hline India Southern & Bsm I \\
\hline Italy & No association \\
\hline Iran & TaqI \\
\hline Japan & BsmI, FokI \\
\hline Norway & No association \\
\hline Polish & No association \\
\hline Portugal & No association \\
\hline Romania & No association \\
\hline Spain & FokI \\
\hline Taiwan & BsmI, ApaI \\
\hline Turkey & FokI \\
\hline United States & No association \\
\hline United Kingdom & No association \\
\hline
\end{tabular}

${ }^{1}$ Combined.

${ }^{2}$ Dalmatian population.

${ }^{3}$ In one study, in combination with TruI, VDR polymorphisms were protective against DM type I.

${ }^{4}$ Combined, only in girls.

Chile [56], and Italy [57]) yielded conflicting results; some showed significant association while others failed to reach statistical significance, as shown in Table 1 . These different results may be related to differences in ethnic background of the populations studied, interactions with other genetic or environmental factors involved in the pathogenesis of TIDM [34], and possibly differences in ultraviolet radiation exposure [58]. In fact, VDR polymorphisms, with the potential exception of the FokI allele variant which has a differential effect on the immune system [59], may not have any functional effect, so, the VDR itself may not be the disease affecting locus but rather a marker locus in linkage disequilibrium with the real disease locus, and the discrepant findings may reflect variable strength of linkage disequilibrium in different populations [41].

The largest meta-analysis to date investigating the association between polymorphisms in VDR gene and T1DM risk found that BsmI polymorphism is associated with a significantly increased risk of T1DM, whereas the FokI, ApaI, and TaqI polymorphisms do not appear to have a significant association with overall T1DM risk. The BsmI variant $B$ allele (BB or $\mathrm{Bb}$ ) carriers might have a $30 \%$ increased risk of T1DM when compared with the bb homozygote carriers [60].
TABLE 2: Mean 25OH D level in T1DM in different countries.

\begin{tabular}{lc}
\hline Country & Mean 25OH D level (nmol/L) \\
\hline Australia & 78.7 \\
Egypt & 46.75 \\
Florida & 53 \\
Qatar & 39.8 \\
Sweden & 82.5 \\
Switzerland & 45.7 \\
USA (North Eastern) & 67 \\
\hline
\end{tabular}

\section{Prevalence of Low Vitamin D Level in Type I DM}

Given the association between vitamin D and T1DM and the possible role that vitamin $\mathrm{D}$ deficiency might play in its pathogenesis, many observational studies have assessed the 25-hydroxyvitamin D (25-OH D) level in T1DM patients (Table 2) and found a significant higher prevalence of 25$\mathrm{OH} \mathrm{D}$ deficiency in T1DM patients compared to controls. In Switzerland, in a cross-sectional study, $60-84 \%$ of T1DM were 25-OH D deficient [61]. In Qatar, in a case control study, $90.6 \%$ of T1DM children versus $85.3 \%$ of nondiabetic children had vitamin D deficiency [62]. Similarly, in North India in a case-control study, $58 \%$ of T1DM and only $32 \%$ of controls had 25-OH D deficiency [63]. In Northeastern US, in a cross-sectional study, it has been found that $15 \%$ of T1D patients were $25-\mathrm{OH} \mathrm{D}$ deficient and $61 \%$ were insufficient, findings inversely associated with age [64]. All these studies showed significantly lower mean 25-OH D level in T1DM compared to controls $[62,63,65-68]$. In addition, in the Diabetes Incidence Study in Sweden (DISS), 25-OH D level was lower in diabetics compared to controls, not only at the onset of diabetes but also at 8-year followup [69].

However, only one study, in Florida, a solar rich region in the United States, found no difference in 25-OH D levels in diabetics (recently or more than 5 months diagnosed) compared to their first degree relatives and controls [70].

A pilot study, comparing 25-OH D level in T1DM and type 2 diabetes mellitus (T2DM) showed a higher prevalence of deficiency in T2DM compared to T1DM, and more severe deficiency, independent of age, sex, BMI, and insulin treatment (mean adjusted 25-OH D level $18.1 \pm 1.4 \mathrm{ng} / \mathrm{mL}$ in T2DM versus $22.9 \pm 1.6 \mathrm{ng} / \mathrm{mL}$ in T1DM) [71].

\section{Effect of Latitude on Vitamin D Level and T1DM Incidence}

Dermal vitamin D synthesis is a major source of circulating 25-OH D and its metabolites [72]. Sun exposure, strongly related to latitude, predicts $25-\mathrm{OH}$ D level. Many observational studies showed increased T1DM prevalence at northern latitudes where sun exposure is reduced [6].

In Australia, an ecologic analysis of immune-related disorders showed a positive association of T1DM prevalence 
with both increasing southern latitude of residence and decreasing regional annual ambient ultraviolet radiation (UVR), with an evident threefold increase in prevalence from the northernmost region to the southernmost region [73]. Similar results were found with increasing latitude in Sweden [74] and China [75]. In Norway, a nationwide prospective study showed higher rate of T1DM in southern county and lowest in northern county [76].

The EURODIAB collaborative, a large multicenter casecontrol study including 7 centers, Austria, Bucharest, Bulgaria, Latvia, Lithuania, Luxembourg, North Ireland representing most European countries and Israel, in a report based on 16362 cases registered during the period 19891994 by 44 centers and covering a population of about 28 million children, found a high incidence rate in northern and north western Europe and low in central, southern, and eastern Europe with the exception of Sardinia which presented higher rates than neighboring countries [77], with reverse prevalence, being higher in southern areas [78]. In a worldwide study assessing the pattern of incidence of diabetes in 51 different countries, according to latitude and solar UVR, the incidence rates were higher at higher latitudes and lower ultraviolet B irradiance, adjusted for cloud cover, as inversely associated with incidence rates [79].

Note that interpretation of international correlations is particularly difficult because there are many confounding factors such as affluence and genetic variation. Within country analysis provides probably more precise information [80].

\section{Seasonal Variability in the Incidence of T1DM}

Variability in sun exposure during pregnancy or early developmental stages in infancy has been also suggested as an important environmental factor influencing T1DM onset, possibly related to changes in 25-OH D levels, with highest birth dates of diabetic patients in spring-summer months with an opposite pattern of disease onset peaking in autumn and winter [80]. Consistent results were found in Ukraine (highest variability in western Europe) [81], Sweden [82], Greece [83], Ireland (significant in boys only) [84], Slovenia [85], Germany [86], The Netherlands [87], Britain [88], New Zealand [89], and Sardinia [90]. However, a multicenter cohort study in Europe found no seasonal variations [91]. Similarly, no significant differences in parameters studied in diabetics and controls were detected in Denmark [92]. In a Lebanese T1D population, El Baba et al. showed seasonal variation in glucose control but failed to establish a significant correlation between seasonal changes in 25-OH D levels and HbAlc $[93,94]$. In fact, ethnicity may be a confounding factor [95]. Furthermore, none of these studies have shown data about 25-OH D levels, given that they were retrospective. Also, given that viral infections-proven to be involved in the pathogenesis of T1DM-may have also seasonal variations, the evidence of vitamin $\mathrm{D}$ involvement in seasonal variations of T1DM needs to be demonstrated with more accurate data.

\section{Vitamin D Supplementation and Risk of Developing T1DM}

Many studies have assessed the effect of vitamin D supplementation during pregnancy, infancy, or early adulthood and the risk of developing T1DM later on in life (Table 3).

The EURODIAB focused on early exposures and risk of T1DM. Vitamin D intake during infancy was assessed by questionnaire or interview (recalled). It showed that vitamin $\mathrm{D}$ supplements (given for the prevention of rickets) have a protective effect, even after adjustment for various confounders [96].

Hyppönen et al., in his finish birth cohort study found that vitamin D supplementation of 200 IU daily (as cod liver oil), given to children, was associated with a lower incidence of T1DM during a follow-up period of 31 years [97].

In the Norway pilot study, Stene et al. demonstrated a protective effect of vitamin D supplements, only when given as cod liver oil to pregnant women and not when given in other forms of supplementation or when given to children, suggesting a protective effect in utero [98]. However, in his larger case control study, he found a protective effect of cod liver oil when given during the first year of life only and when given $\geq 5$ times per week. No protective effect was detected if vitamin $\mathrm{D}$ was given during pregnancy, conflicting results with what have been shown previously by the same group for unknown reasons [99].

Similarly, in the DAISY (Diabetes Autoimmunity Study in the Young) study in Colorado, that recruited at birth and followed children at increased risk for T1DM, as determined by HLA-DR genotype or by family history of T1DM, there was a protective effect of vitamin $\mathrm{D}$ taken through food only and not as supplements [100]. More recently, Tenconi et al. demonstrated a protective effect of vitamin $\mathrm{D}$ given during lactation [101].

The ABIS (All Babies in Southeast Sweden) study is a large, prospective, population-based cohort study in Sweden that found vitamin D supplementation, given as drops $10 \mathrm{mcg}$ daily, decreased significantly the incidence of glutamic acid decarboxylase autoantibodies or IA-2A in the offspring at 1 year, but not at 2.5 years [102].

Furthermore, the Diabetes Prediction and Prevention study (DIPP), which is a population-based birth cohort of infants at genetic risk of T1DM, showed no significant protective effects of vitamin $\mathrm{D}$ whether given with food or as supplements [103].

A meta-analysis of the results of observational studies suggests that the risk of T1DM is $29 \%$ reduced in those who were supplemented in childhood with vitamin D compared to those who were not [104]. There was some evidence of doseresponse effect-higher supplementation resulting in better protection-and the timing of supplementation predicted a favorable response when given between 7 and 12 months, critical period for immunity to become competent [105].

To note that all these studies have several limitations including recall bias, the absence of 25-OH D level, and the absence of quantitative assessment of vitamin D intake; the dose of vitamin $\mathrm{D}$ given was not always mentioned. Randomized controlled trials with long periods of followup 


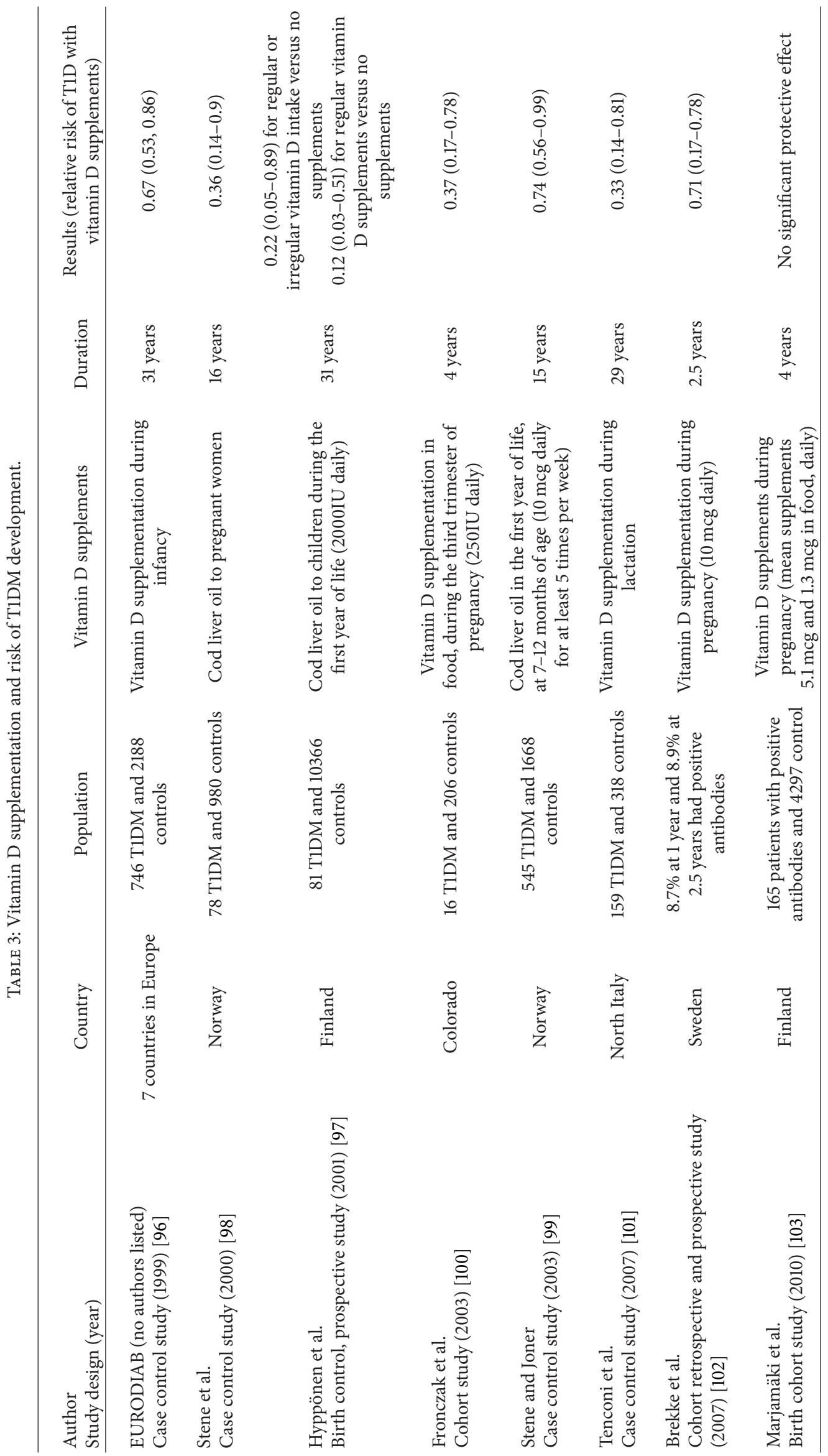


are needed to establish causality and to suggest the best formulation, dose, duration, and period of supplementation with vitamin $\mathrm{D}$ that would allow appropriate protection against T1DM [104].

\section{Possible Explanation of Vitamin D Deficiency in Diabetes}

One of the plausible mechanisms of vitamin $\mathrm{D}$ deficiency in diabetics is decreased binding proteins; this has been initially demonstrated in diabetic rats [106]. Later on, in humans, it has been found that the urinary loss of vitamin $\mathrm{D}$ binding protein (VDBP) is secondary to diminished function or availability of megalin or low-density lipoproteinrelated protein 2 (LRP2), correlated with proteinuria. In fact, Megalin is a receptor to many ligands, including albumin, vitamin-binding protein, lipoproteins, hormones, enzymes, and drugs responsible for their reabsorption in the proximal tubule. It facilitates the generation of $1,25(\mathrm{OH})_{2} \mathrm{D}_{3}$ following the reabsorption of the $\mathrm{VDBP}-25 \mathrm{OHD}$ complex by via megalin endocytic receptor [107]. Furthermore, a study on pubertal T1DM patients showed altered vitamin $\mathrm{D}$ regulatory mechanisms with relative decrease in $1,25(\mathrm{OH})_{2} \mathrm{D}_{3}$ plasma concentration and increased 24,25-dihydroxyvitamin D levels in diabetics compared to their healthy counterparts [68]. Note that 25-OH D level upon presentation with diabetic ketoacidosis can be falsely lowered by acidosis and improves with its resolution without any supplementation [108].

\section{Vitamin D Deficiency and Risk of Diabetic Complications}

Vitamin D deficiency is associated with increased inflammatory markers in diabetics including CRP, monocyte tolllike receptor (TLR) 2, TLR4, and nuclear factor $\kappa \mathrm{B}(\mathrm{NF} \kappa \mathrm{B})$ expression; this might predict increased microvascular complications. However, no statistically significant difference was found in 25-OH D levels in diabetics with microvascular complications compared to those without [109]. On the other hand, another study showed that persistent microalbuminuria is associated with lower 25-OH D levels in T1DM compared to controls [110]. Cardiovascular diseases increased with low 25-OH D levels in the general population [111] but these results have not been specifically studied in diabetics.

25-OH D deficiency has been prevalent upon the initial presentation of T1DM patients who presented with DKA, making it a contributing factor. However, given that levels improved spontaneously after correction of acidosis, the direct contribution of $25-\mathrm{OH} \mathrm{D}$ deficiency in the acute presentation of DKA remains controversial [108].

\section{Vitamin D Supplementation Effect on Progression and Control of Diabetes}

Given that vitamin D deficiency increases the risk of diabetes development and supplementation showed protective effects, many studies looked at the protective effect of vitamin D on diabetes progression and control. One randomized controlled study aimed to assess the effect calcitriol (given as $0.25 \mathrm{mcg}$ every other day) compared to nicotinamide, within 4 weeks of diabetes diagnosis, on the preservation of $\beta$-cell function; it showed no improvement in C-peptide and HbAlc levels but significantly lower insulin doses in the calcitriol-treated group [112]. Even when the dose of calcitriol was increased to $0.25 \mathrm{mcg}$ daily and after a followup of 2 years, there was no protective effect of such supplementation on C-peptide levels [113]. Conversely, in LADA patients, when calcitriol ( 0.5 mcg daily) was added to insulin, it showed stabilization or improvement in fasting and $2 \mathrm{~h}$ after 75 -g glucose load $\mathrm{C}$-peptide level at 1 year, especially in those whose diabetes duration was less than 1 year [114]. Similarly, in a study in Saudi Arabia, vitamin $\mathrm{D}_{3}$ supplementation to T1DM patients who were deficient showed improvement in glucose control (with significantly lower HbAlc) when $25 \mathrm{OH}$ D level reached $>75 \mathrm{nmol} / \mathrm{L}$ at 12 weeks [115].

\section{Guidelines of Vitamin D Supplementation in Children}

The American Academy of Pediatrics and the Canadian Pediatric Association recommended vitamin D supplementation of 400 IU daily, starting the first few days of life [116]. The Institute of Medicine (IOM) recommended that the adequate intake and RDA for children below 1 year of age is $400 \mathrm{IU} / \mathrm{d}$ and for all individuals of 1 year to 70 years should be $600 \mathrm{IU} / \mathrm{d}$ [117]. It seems prudent to ensure that all infants in the United States and other areas with comparable sunlight exposure receive enough vitamin $\mathrm{D}$, especially in winter [118]. Whether these recommended doses are enough to allow extraskeletal benefits of vitamin D is still unknown.

Until now, no specific recommendations regarding vitamin D supplementation in patients with T1DM or at risk of developing autoimmune diabetes [119] but intakes between 5 mcg daily and the $25 \mathrm{mcg}$ daily, tolerable upper intake level, may be desirable [118].

\section{Conclusion}

$1,25(\mathrm{OH})_{2} \mathrm{D}_{3}$ immunomodulatory effects have shown significant protection against pancreatic insulitis in animal studies [13-18, 21, 22, 120, 121]. In humans, retrospective analysis and observational studies demonstrated high prevalence of 25-OH D deficiency in patients with T1DM [61-68] and suggested a contributory role in the pathogenesis of T1DM, specially with certain allelic variations of the VDR [32-57]. Conversely, vitamin D supplementation during pregnancy and early childhood decreased the risk of autoimmune diabetes [96-104] and perhaps, even after the onset of diabetes, it may improve glycemic control $[114,115]$. Despite all these data, the best dose to be used and the target population in order to decrease the incidence of T1DM have not been yet defined. Abiding by the IOM and the American Academy of Pediatrics recommendations on vitamin D supplementations, at least, improves the $25 \mathrm{OH} \mathrm{D}$ level. 


\section{References}

[1] L. C. Harrison, M. C. Honeyman, G. Morahan et al., "Type 1 diabetes: lessons for other autoimmune diseases?" Journal of Autoimmunity, vol. 31, no. 3, pp. 306-310, 2008.

[2] M. E. Craig, A. Hattersley, and K. Donaghue, "Definition, epidemiology and classification of diabetes in children and adolescents," Pediatric Diabetes, vol. 7, no. 10, supplement 12, pp. 3-12, 2009.

[3] N. Lammi, O. Taskinen, E. Moltchanova et al., "A high incidence of type 1 diabetes and an alarming increase in the incidence of type 2 diabetes among young adults in Finland between 1992 and 1996," Diabetologia, vol. 50, no. 7, pp. 1393-1400, 2007.

[4] G. P. Forlenza and M. Rewers, "The epidemic of type 1 diabetes: what is it telling us?" Current Opinion in Endocrinology, Diabetes and Obesity, vol. 18, no. 4, pp. 248-251, 2011.

[5] L. Moroni, I. Bianchi, and A. Lleo, "Geoepidemiology, gender and autoimmune disease," Autoimmunity Reviews, vol. 11, pp. A386-A392, 2012.

[6] M. A. Kriegel, J. E. Manson, and K. H. Costenbader, "Does vitamin $\mathrm{D}$ affect risk of developing autoimmune disease?: a systematic review," Seminars in Arthritis and Rheumatism, vol. 40, no. 6, pp. 512-531, 2011.

[7] M. Cutolo, C. Pizzorni, and A. Sulli, "Vitamin D endocrine system involvement in autoimmune rheumatic diseases," Autoimmunity Reviews, vol. 11, pp. 84-87, 2011.

[8] S. Nagpal, S. Na, and R. Rathnachalam, "Noncalcemic actions of vitamin D receptor ligands," Endocrine Reviews, vol. 26, no. 5, pp. 662-687, 2005.

[9] E. van Etten and C. Mathieu, "Immunoregulation by 1,25dihydroxyvitamin D3: basic concepts," Journal of Steroid Biochemistry and Molecular Biology, vol. 97, no. 1-2, pp. 93-101, 2005.

[10] S. Lee, S. A. Clark, R. K. Gill, and S. Christakos, "1,25Dihydroxyvitamin D3 and pancreatic $\beta$-cell function: vitamin D receptors, gene expression, and insulin secretion," Endocrinology, vol. 134, no. 4, pp. 1602-1610, 1994.

[11] J. B. Zella, L. C. McCary, and H. F. DeLuca, "Oral administration of 1,25-dihydroxyvitamin D3 completely protects NOD mice from insulin-dependent diabetes mellitus," Archives of Biochemistry and Biophysics, vol. 417, no. 1, pp. 77-80, 2003.

[12] A. Giulietti, C. Gysemans, K. Stoffels et al., "Vitamin D deficiency in early life accelerates Type 1 diabetes in non-obese diabetic mice," Diabetologia, vol. 47, no. 3, pp. 451-462, 2004.

[13] C. Mathieu, J. Laureys, H. Sobis, M. Vandeputte, M. Waer, and R. Bouillon, "1,25-Dihydroxyvitamin D3 prevents insulitis in NOD mice," Diabetes, vol. 41, no. 11, pp. 1491-1495, 1992.

[14] K. M. Casteels, C. Mathieu, M. Waer et al., "Prevention of type I diabetes in NOD mice by nonhypercalcemic doses of a new structural analog of 1,25-dihydroxyvitamin D3, KH1060," Endocrinology, vol. 136, no. 3, pp. 866-872, 1995.

[15] C. A. Gysemans, A. K. Cardozo, H. Callewaert et al., "1,25Dihydroxyvitamin D3 modulates expression of chemokines and cytokines in pancreatic islets: implications for prevention of diabetes in nonobese diabetic mice," Endocrinology, vol. 146, no. 4, pp. 1956-1964, 2005.

[16] N. Giarratana, G. Penna, S. Amuchastegui, R. Mariani, K. C. Daniel, and L. Adorini, "A vitamin D analog down-regulates proinflammatory chemokine production by pancreatic islets inhibiting T cell recruitment and type 1 diabetes development," Journal of Immunology, vol. 173, no. 4, pp. 2280-2287, 2004.
[17] S. Gregori, N. Giarratana, S. Smiroldo, M. Uskokovic, and L. Adorini, "A $1 \alpha, 25$-dihydroxyvitamin D3 analog enhances regulatory T-cells and arrests autoimmune diabetes in NOD mice," Diabetes, vol. 51, no. 5, pp. 1367-1374, 2002.

[18] R. Riachy, B. Vandewalle, S. Belaich et al., "Beneficial effect of 1,25 dihydroxyvitamin D3 on cytokine-treated human pancreatic islets," Journal of Endocrinology, vol. 169, no. 1, pp. 161-168, 2001.

[19] J. A. Emamaullee, J. Davis, S. Merani et al., "Inhibition of Th17 cells regulates autoimmune diabetes in NOD mice," Diabetes, vol. 58, no. 6, pp. 1302-1311, 2009.

[20] Y. Arnson, H. Amital, and Y. Shoenfeld, "Vitamin D and autoimmunity: new aetiological and therapeutic considerations," Annals of the Rheumatic Diseases, vol. 66, no. 9, pp. 11371142, 2007.

[21] C. Mathieu, M. Waer, J. Laureys, O. Rutgeerts, and R. Bouillon, "Prevention of autoimmune diabetes in NOD mice by 1,25 dihydroxyvitamin D3," Diabetologia, vol. 37, no. 6, pp. 552-558, 1994.

[22] C. Mathieu, M. Waer, K. Casteels, J. Laureys, and R. Bouillon, "Prevention of type I diabetes in NOD mice by nonhypercalcemic doses of a new structural analog of 1,25dihydroxyvitamin D3, KH1060," Endocrinology, vol. 136, no. 3, pp. 866-872, 1995.

[23] L. Overbergh, B. Decallonne, M. Waer et al., " $1 \alpha, 25$ dihydroxyvitamin D3 induces an autoantigen-specific T-helper 1/T-helper 2 immune shift in NOD mice immunized with GAD65 (p524-543)," Diabetes, vol. 49, no. 8, pp. 1301-1307, 2000.

[24] A. L. Khoo, I. Joosten, and M. Michels, "1, 25-Dihydroxyvitamin D3 inhibits proliferation but not the suppressive function of regulatory T cells in the absence of antigen-presenting cells," Immunology, vol. 134, no. 4, pp. 459-468, 2011.

[25] R. Riachy, B. Vandewalle, J. K. Conte et al., "1,25-dihydroxyvitamin D3 protects RINm5F and human islet cells against cytokine-induced apoptosis: implication of the antiapoptotic protein A20," Endocrinology, vol. 143, no. 12, pp. 4809-4819, 2002.

[26] A. Y. Savinov, A. Tcherepanov, and E. A. Green, "Contribution of Fas to diabetes development," Proceedings of the National Academy of Sciences of the United States of America, vol. 100, pp. 628-632, 2003.

[27] R. Riachy, B. Vandewalle, E. Moerman et al., "1,25-dihydroxyvitamin D3 protects human pancreatic islets against cytokineinduced apoptosis via down-regulation of the Fas receptor," Apoptosis, vol. 11, no. 2, pp. 151-159, 2006.

[28] S. Nagpal, S. Na, and R. Rathnachalam, "Noncalcemic actions of vitamin D receptor ligands," Endocrine Reviews, vol. 26, no. 5, pp. 662-687, 2005.

[29] A. G. Uitterlinden, Y. Fang, J. B. J. Van Meurs, H. A. P. Pols, and J. P. T. M. Van Leeuwen, "Genetics and biology of vitamin D receptor polymorphisms," Gene, vol. 338, no. 2, pp. 143-156, 2004.

[30] A. F. Reis, O. M. Hauache, and G. Velho, "Vitamin D endocrine system and the genetic susceptibility to diabetes, obesity and vascular disease. A review of evidence," Diabetes and Metabolism, vol. 31, no. 4, part 1, pp. 318-325, 2005.

[31] E. Ramos-Lopez, T. Jansen, V. Ivaskevicius et al., "Protection from type 1 diabetes by vitamin D receptor haplotypes," Annals of the New York Academy of Sciences, vol. 1079, pp. 327-334, 2006. 
[32] M. F. McDermott, A. Ramachandran, B. W. Ogunkolade et al., "Allelic variation in the vitamin D receptor influences susceptibility to IDDM in Indian Asians," Diabetologia, vol. 40, no. 8, pp. 971-975, 1997.

[33] N. Israni, R. Goswami, A. Kumar, and R. Rani, "Interaction of Vitamin D receptor with HLA DRB $* 0301$ in Type 1 diabetes patients from North India," PLoS ONE, vol. 4, no. 12, Article ID e8023, 2009.

[34] Z. Mohammadnejad, M. Ghanbari, R. Ganjali et al., "Association between vitamin $\mathrm{D}$ receptor gene polymorphisms and type 1 diabetes mellitus in Iranian population," Molecular Biology Reports, vol. 39, no. 2, pp. 831-837, 2012.

[35] G. Martí, L. Audí, C. Esteban et al., "Association of vitamin D receptor gene polymorphism with type 1 diabetes mellitus in two Spanish populations," Medicina Clinica, vol. 123, no. 8, pp. 286-290, 2004.

[36] S. Nejentsev, J. D. Cooper, L. Godfrey et al., "Analysis of the vitamin D receptor gene sequence variants in type 1 diabetes," Diabetes, vol. 53, no. 10, pp. 2709-2712, 2004.

[37] C. Guja, S. Marshall, K. Welsh et al., "The study of CTLA4 and vitamin D receptor polymorphisms in the Romanian type 1 diabetes population," Journal of Cellular and Molecular Medicine, vol. 6, no. 1, pp. 75-81, 2002.

[38] S. B. Sahin, S. Cetinkalp, and M. Erdogan, "Fas, Fas ligand, and vitamin D receptor fokI gene polymorphisms in patients with Type 1 diabetes mellitus in the aegean region of Turkey," Genet Test Mol Biomarkers, vol. 16, no. 10, pp. 1179-1183, 2012.

[39] D. Gogas Yavuz, L. Keskin, S. Kıyıc1 et al., "Vitamin D receptor gene BsmI, FokI, ApaI, TaqI polymorphisms and bone mineral density in a group of Turkish type 1 diabetic patients," Acta Diabetologica, vol. 48, no. 4, pp. 329-336, 2011.

[40] B. Györffy, B. Vásárhelyi, D. Krikovszky et al., "Gender-specific association of vitamin D receptor polymorphism combinations with type 1 diabetes mellitus," European Journal of Endocrinology, vol. 147, no. 6, pp. 803-808, 2002.

[41] M. Lemosa, A. Fagulhab, and E. Coutinhoc, "Lack of association of vitamin D receptor gene polymorphisms with susceptibility to type 1 diabetes mellitus in the Portuguese population," Human Immunology, vol. 69, pp. 134-138, 2008.

[42] A. Shimada, Y. Kanazawa, Y. Motohashi et al., "Evidence for association between vitamin D receptor BsmI polymorphism and type 1 diabetes in Japanese," Journal of Autoimmunity, vol. 30, no. 4, pp. 207-211, 2008.

[43] Y. Ban, M. Taniyama, T. Yanagawa et al., "Vitamin D receptor initiation codon polymorphism influences genetic susceptibility to type 1 diabetes mellitus in the Japanese population," $B M C$ Medical Genetics, vol. 2, article 7, 2001.

[44] H. Turpeinen, R. Hermann, S. Vaara et al., "Vitamin D receptor polymorphisms: no association with type 1 diabetes in the Finnish population," European Journal of Endocrinology, vol. 149, no. 6, pp. 591-596, 2003.

[45] M. Fichna, M. Zurawek, D. Januszkiewicz-Lewandowska, P. Fichna, and J. Nowak, "PTPN22, PDCD1 and CYP27B1 polymorphisms and susceptibility to type 1 diabetes in Polish patients," International Journal of Immunogenetics, vol. 37, no. 5, pp. 367-372, 2010.

[46] V. Boraska, V. Škrabić, E. Zeggini et al., "Family-based analysis of vitamin $\mathrm{D}$ receptor gene polymorphisms and type 1 diabetes in the population of South Croatia," Journal of Human Genetics, vol. 53, no. 3, pp. 210-214, 2008.

[47] T. Zemunik, V. Škrabić, V. Boraska et al., "Fokl polymorphism, vitamin D receptor, and interleukin-1 receptor haplotypes are associated with type 1 diabetes in the Dalmatian population," Journal of Molecular Diagnostics, vol. 7, no. 5, pp. 600-604, 2005.

[48] D. B. Mory, E. R. Rocco, W. L. Miranda, T. Kasamatsu, F. Crispim, and S. A. Dib, "Prevalence of vitamin D receptor gene polymorphisms FokI and BsmI in Brazilian individuals with type 1 diabetes and their relation to $\beta$-cell autoimmunity and to remaining $\beta$-cell function," Human Immunology, vol. 70, no. 6, pp. 447-451, 2009.

[49] A. Mimbacas, J. Trujillo, C. Gascue, G. Javiel, and H. Cardoso, "Prevalence of vitamin D receptor gene polymorphism in a Uruguayan population and its relation to type 1 diabetes mellitus," Genetics and Molecular Research, vol. 6, no. 3, pp. 534542, 2007.

[50] W. J. Fassbender, B. Goertz, K. Weismüller et al., "VDR gene polymorphisms are overrepresented in German patients with type 1 diabetes compared to healthy controls without effect on biochemical parameters of bone metabolism," Hormone and Metabolic Research, vol. 34, no. 6, pp. 330-337, 2002.

[51] M. A. Pani, M. Knapp, H. Donner et al., "Vitamin D receptor allele combinations influence genetic susceptibility to 1 diabetes in Germans," Diabetes, vol. 49, no. 3, pp. 504-507, 2000.

[52] E. Ramos-Lopez, T. Jansen, V. Ivaskevicius et al., "Protection from type 1 diabetes by vitamin D receptor haplotypes," Annals of the New York Academy of Sciences, vol. 1079, pp. 327-334, 2006.

[53] C. Panierakis, G. Goulielmos, D. Mamoulakis, E. Petraki, E. Papavasiliou, and E. Galanakis, "Vitamin D receptor gene polymorphisms and susceptibility to type 1 diabetes in Crete, Greece," Clinical Immunology, vol. 133, no. 2, pp. 276-281, 2009.

[54] B. W. Ogunkolade, B. J. Boucher, J. M. Prahl et al., "Vitamin D receptor (VDR) mRNA and VDR protein levels in relation to vitamin D status, insulin secretory capacity, and VDR genotype in Bangladeshi Asians," Diabetes, vol. 51, no. 7, pp. 2294-2300, 2002.

[55] T. J. Chang, H. H. Lei, J. I. Yeh et al., "Vitamin D receptor gene polymorphisms influence susceptibility to type 1 diabetes mellitus in the Taiwanese population," Clinical Endocrinology, vol. 52, no. 5, pp. 575-580, 2000.

[56] D. García, B. Angel, E. Carrasco, C. Albala, J. L. Santos, and F. Pérez-Bravo, "VDR polymorphisms influence the immune response in type 1 diabetic children from Santiago, Chile," Diabetes Research and Clinical Practice, vol. 77, no. 1, pp. 134140, 2007.

[57] M. G. Bianco, L. Minicucci, M. G. Calevo, and R. Lorini, "Vitamin D receptor polymorphisms: are they really associated with type 1 diabetes?" European Journal of Endocrinology, vol. 151, no. 5, pp. 641-642, 2004.

[58] A. L. Ponsonby, A. Pezic, J. Ellis et al., "Variation in associations between allelic variants of the vitamin $\mathrm{D}$ receptor gene and onset of type 1 diabetes mellitus by ambient winter ultraviolet radiation levels: a meta-regression analysis," American Journal of Epidemiology, vol. 168, no. 4, pp. 358-365, 2008.

[59] E. Van Etten, L. Verlinden, A. Giulietti et al., "The vitamin D receptor gene FokI polymorphism: functional impact on the immune system," European Journal of Immunology, vol. 37, no. 2, pp. 395-405, 2007.

[60] J. Zhang, W. Li, and J. Liu, "Polymorphisms in the vitamin D receptor gene and type 1 diabetes mellitus risk: an update by meta-analysis," Molecular and Cellular Endocrinology, vol. 355, pp. 135-142, 2012.

[61] M. Janner, P. Ballinari, P. E. Mullis, and C. E. Flück, "High prevalence of vitamin $\mathrm{D}$ deficiency in children and adolescents 
with type 1 diabetes," Swiss Medical Weekly, vol. 140, p. w13091, 2010.

[62] A. Bener, A. Alsaied, M. Al-Ali et al., "High prevalence of vitamin $\mathrm{D}$ deficiency in type 1 diabetes mellitus and healthy children," Acta Diabetologica, vol. 46, no. 3, pp. 183-189, 2009.

[63] V. V. Borkar, V. S. Devidayal, and A. K. Bhalla, "Low levels of vitamin D in North Indian children with newly diagnosed type 1 diabetes," Pediatric Diabetes, vol. 11, no. 5, pp. 345-350, 2010.

[64] B. M. Svoren, L. K. Volkening, J. R. Wood, and L. M. B. Laffel, "Significant vitamin D deficiency in youth with type 1 diabetes mellitus," Journal of Pediatrics, vol. 154, no. 1, pp. 132-134, 2009.

[65] P. Pozzilli, S. Manfrini, A. Crinò et al., "Low levels of 25hydroxyvitamin D3 and 1,25-dihydroxyvitamin D3 in patients with newly diagnosed type 1 diabetes," Hormone and Metabolic Research, vol. 37, no. 11, pp. 680-683, 2005.

[66] R. M. Greer, S. L. Portelli, and B. S. Hung, "Serum vitamin D levels are lower in Australian children and adolescents with type 1 diabetes than in children without diabetes," Pediatric Diabetes, vol. 14, no. 1, pp. 31-41, 2012.

[67] E. A. Hamed, N. H. Faddan, and H. A. Elhafeez, "Parathormone $-25(\mathrm{OH})$-vitamin $\mathrm{D}$ axis and bone status in children and adolescents with type 1 diabetes mellitus," Pediatr Diabete, vol. 12, no. 6, pp. 536-546, 2011.

[68] O. Rodland, T. Markestad, L. Aksnes, and D. Aarskog, "Plasma concentration of vitamin $\mathrm{D}$ metabolites during puberty of diabetic children," Diabetologia, vol. 28, no. 9, pp. 663-666, 1985.

[69] B. Littorin, P. Blom, A. Schölin et al., "Lower levels of plasma 25-hydroxyvitamin D among young adults at diagnosis of autoimmune type 1 diabetes compared with control subjects: results from the nationwide Diabetes Incidence Study in Sweden (DISS)," Diabetologia, vol. 49, no. 12, pp. 2847-2852, 2006.

[70] L. Bierschenk, J. Alexander, C. Wasserfall, M. Haller, D. Schatz, and M. Atkinson, "Vitamin D levels in subjects with and without type 1 diabetes residing in a solar rich environment," Diabetes Care, vol. 32, no. 11, pp. 1977-1979, 2009.

[71] D. J. Di Cesar, R. Ploutz-Snyder, R. S. Weinstock, and A. M. Moses, "Vitamin D deficiency is more common in type 2 than in type 1 diabetes [6]," Diabetes Care, vol. 29, no. 1, p. 174, 2006.

[72] H. F. DeLuca, "Overview of general physiologic features and functions of vitamin D," The American Journal of Clinical Nutrition, vol. 80, no. 6, supplement, pp. 1689S-1696S, 2004.

[73] J. A. Staples, A. L. Ponsonby, L. L. Y. Lim, and A. J. McMichael, "Ecologic analysis of some immune-related disorders, including type 1 diabetes, in Australia: iatitude, regional ultraviolet radiation, and disease prevalence," Environmental Health Perspectives, vol. 111, no. 4, pp. 518-523, 2003.

[74] L. Nystrom, G. Dahlquist, J. Ostman et al., "Risk of developing insulin-dependent diabetes mellitus (IDDM) before 35 years of age: indications of climatological determinants for age at onset," International Journal of Epidemiology, vol. 21, no. 2, pp. 352-358, 1992.

[75] Z. Yang, K. Wang, L. I. Tianlin et al., "Childhood diabetes in China: enormous variation by place and ethnic group," Diabetes Care, vol. 21, no. 4, pp. 525-529, 1998.

[76] G. Joner, L. C. Stene, and O. Søvik, "Nationwide, prospective registration of type 1 diabetes in children aged $<15$ years in Norway 1989-1998: no increase but significant regional variation in incidence," Diabetes Care, vol. 27, no. 7, pp. 16181622, 2004.

[77] "Variation and trends in incidence of childhood diabetes in Europe," The Lancet, vol. 355, no. 9207, pp. 873-876, 2000.
[78] A. Casu, C. Pascutto, L. Bernardinelli, and M. Songini, "Bayesian approach to study the temporal trend and the geographical variation in the risk of type 1 diabetes: the Sardinian Conscript type 1 diabetes registry," Pediatric Diabetes, vol. 5, no. 1, pp. 32-38, 2004.

[79] S. B. Mohr, C. F. Garland, E. D. Gorham, and F. C. Garland, "The association between ultraviolet B irradiance, vitamin D status and incidence rates of type 1 diabetes in 51 regions worldwide," Diabetologia, vol. 51, no. 8, pp. 1391-1398, 2008.

[80] T. R. Merriman, “Type 1 diabetes, the A1 milk hypothesis and vitamin D deficiency," Diabetes Research and Clinical Practice, vol. 83, no. 2, pp. 149-156, 2009.

[81] A. M. Vaiserman, B. Carstensen, V. P. Voitenko et al., "Seasonality of birth in children and young adults (0-29 years) with type 1 diabetes in Ukraine," Diabetologia, vol. 50, no. 1, pp. 32-35, 2007.

[82] U. Samuelsson, C. Johansson, and J. Ludvigsson, "Month of birth and risk of developing insulin dependent diabetes in south east Sweden," Archives of Disease in Childhood, vol. 81, no. 2, pp. 143-146, 1999.

[83] M. I. Kalliora, A. Vazeou, D. Delis, E. Bozas, I. Thymelli, and C. S. Bartsocas, "Seasonal variation of type 1 diabetes mellitus diagnosis in Greek children," Hormones, vol. 10, no. 1, pp. 67-71, 2011.

[84] E. F. Roche, H. Lewy, H. M. C. V. Hoey, and Z. Laron, "Differences between males and females in the seasonality of birth and month of clinical onset of disease in chilren with type 1 diabetes mellitus in Ireland," Journal of Pediatric Endocrinology and Metabolism, vol. 16, no. 5, pp. 779-782, 2003.

[85] N. Ursic-Bratina, T. Battelino, C. Kržišnik, T. Laron-Kenet, I. Ashkenazi, and Z. Laron, "Seasonality of birth in children (014 years) with type 1 diabetes mellitus in Slovenia," Journal of Pediatric Endocrinology and Metabolism, vol. 14, no. 1, pp. 4752, 2001.

[86] O. Kordonouri, N. Shuga, H. Lewy, I. Ashkenazi, and Z. Laron, "Seasonality of month of birth of children and adolescents with type 1 diabetes mellitus in Berlin differs from the general population," European Journal of Pediatrics, vol. 161, no. 5, pp. 291-292, 2002.

[87] P. H. Jongbloet, H. M. Groenewoud, R. A. Hirasing, and S. Van Buuren, "Seasonality of birth in patients with childhood diabetes in The Netherlands," Diabetes Care, vol. 21, no. 1, pp. 190-191, 1998.

[88] P. M. Rothwell, A. Staines, P. Smail, E. Wadsworth, and P. McKinney, "Seasonality of birth of patients with childhood diabetes in Britain," British Medical Journal, vol. 312, no. 7044, pp. 1456-1457, 1996.

[89] J. A. Willis, R. S. Scott, B. A. Darlow, H. Lewy, I. Ashkenazi, and Z. Laron, "Seasonality of birth and onset of clinical disease in children and adolescents (0-19 years) with type 1 diabetes mellitus in Canterbury, New Zealand," Journal of Pediatric Endocrinology and Metabolism, vol. 15, no. 5, pp. 645-647, 2002.

[90] M. Songini, A. Casu, I. Ashkenazi, and Z. Laron, "Seasonality of birth in children ( $0-14$ years) and young adults ( $0-29$ years) with type 1 diabetes mellitus in Sardinia differs from that in the general population," Journal of Pediatric Endocrinology and Metabolism, vol. 14, no. 6, pp. 781-783, 2001.

[91] P. M. Rothwell, S. A. Gutnikov, P. A. McKinney, E. Schober, C. Ionescu-Tirgoviste, and A. Neu, "Seasonality of birth in children with diabetes in Europe: multicentre cohort study," British Medical Journal, vol. 319, no. 7214, pp. 887-888, 1999. 
[92] T. Bock, C. R. Pedersen, A. Volund, C. S. Pallesen, and K. Buschard, "Perinatal determinants among children who later develop IDDM," Diabetes Care, vol. 17, no. 10, pp. 1154-1157, 1994.

[93] K. El Baba, M. S. Zantout, A. Arabi, and S. T. Azar, "Seasonal variations of glucose control in Lebanese patients with type 1 diabetes," Biological Rhythm Research, vol. 41, no. 2, pp. 91-97, 2010.

[94] K. El Baba, M. Zantout, R. Akel, and S. Azar, "Seasonal variation in vitamin $\mathrm{D}$ and $\mathrm{HbA}(1 \mathrm{c})$ levels in patients with type 1 diabetes mellitus in the Middle East," International Journal of General Medicine, vol. 4, pp. 635-638, 2011.

[95] Z. Laron, H. Lewy, I. Wilderman et al., "Seasonality of month of birth of children and adolescents with type 1 diabetes mellitus in homogenous and heterogeneous populations," Israel Medical Association Journal, vol. 7, no. 6, pp. 381-384, 2005.

[96] "Vitamin D supplement in early childhood and risk for Type I (insulin- dependent) diabetes mellitus," Diabetologia, vol. 42, no. 1, pp. 51-54, 1999.

[97] E. Hyppönen, E. Läärä, A. Reunanen, M. R. Järvelin, and S. M. Virtanen, "Intake of vitamin D and risk of type 1 diabetes: a birth-cohort study," The Lancet, vol. 358, no. 9292, pp. 15001503, 2001.

[98] L. C. Stene, J. Ulriksen, P. Magnus, and G. Joner, "Use of cod liver oil during pregnancy associated with lower risk of Type I diabetes in the offspring," Diabetologia, vol. 43, no. 9, pp. 10931098, 2000.

[99] L. C. Stene and G. Joner, "Use of cod liver oil during the first year of life is associated with lower risk of childhood-onset type 1 diabetes: a large, population-based, case-control study," American Journal of Clinical Nutrition, vol. 78, no. 6, pp. 11281134, 2003.

[100] C. M. Fronczak, A. E. Barón, H. P. Chase et al., "In utero dietary exposures and risk of islet autoimmunity in children," Diabetes Care, vol. 26, no. 12, pp. 3237-3242, 2003.

[101] M. T. Tenconi, G. Devoti, M. Comelli et al., "Major childhood infectious diseases and other determinants associated with type 1 diabetes: a case-control study," Acta Diabetologica, vol. 44, no. 1, pp. 14-19, 2007.

[102] H. K. Brekke and J. Ludvigsson, "Vitamin D supplementation and diabetes-related autoimmunity in the ABIS study," Pediatric Diabetes, vol. 8, no. 1, pp. 11-14, 2007.

[103] L. Marjamäki, S. Niinistö, M. G. Kenward et al., "Maternal intake of vitamin D during pregnancy and risk of advanced beta cell autoimmunity and type 1 diabetes in offspring," Diabetologia, vol. 53, no. 8, pp. 1599-1607, 2010.

[104] C. S. Zipitis and A. K. Akobeng, "Vitamin D supplementation in early childhood and risk of type 1 diabetes: a systematic review and meta-analysis," Archives of Disease in Childhood, vol. 93, no. 6, pp. 512-517, 2008.

[105] A. Antico, M. Tampoia, R. Tozzoli, and N. Bizzaro, "Can supplementation with Vitamin D reduce the risk or modify the course of autoimmune diseases? A systamatic review of the literature," Autoimmunity Reviews, vol. 12, pp. 127-136, 2012.

[106] B. L. Nyomba, J. Verhaeghe, M. Thomasset, W. Lissens, and R. Bouillon, "Bone mineral homeostasis in spontaneously diabetic $\mathrm{BB}$ rats. I. Abnormal vitamin D metabolism and impaired active intestinal calcium absorption," Endocrinology, vol. 124, no. 2, pp. 565-572, 1989.
[107] K. M. Thrailkill, C. H. Jo, and G. E. Cockrell, "Enhanced excretion of vitamin D binding protein in type 1 diabetes: a role in vitamin D deficiency?" The Journal of Clinical Endocrinology \& Metabolism, vol. 96, no. 1, pp. 142-149, 2011.

[108] T. Huynh, R. M. Greer, O. Nyunt et al., “The association between ketoacidosis and 25(OH)-vitamin D3 levels at presentation in children with type 1 diabetes mellitus," Pediatric Diabetes, vol. 10, no. 1, pp. 38-43, 2009.

[109] S. Devaraj, J. M. Yun, C. R. Duncan-Staley, and I. Jialal, "Low vitamin d levels correlate with the proinflammatory state in type 1 diabetic subjects with and without microvascular complications," American Journal of Clinical Pathology, vol. 135, no. 3, pp. 429-433, 2011.

[110] A. Verrotti, F. Basciani, F. Carle, G. Morgese, and F. Chiarelli, "Calcium metabolism in adolescents and young adults with type 1 diabetes mellitus without and with persistent microalbuminuria," Journal of Endocrinological Investigation, vol. 22, no. 3, pp. 198-202, 1999.

[111] S. Judd, V. Tangpricha, and D. Vitamin, "Deficiency and risk for cardiovascular disease," Circulation, vol. 117, no. 4, pp. 503-511, 2008.

[112] D. Pitocco, A. Crinò, E. Di Stasio et al., "The effects of calcitriol and nicotinamide on residual pancreatic $\beta$-cell function in patients with recent-onset Type 1 diabetes (IMDIAB XI)," Diabetic Medicine, vol. 23, no. 8, pp. 920-923, 2006.

[113] C. Bizzarri, D. Pitocco, N. Napoli et al., "No protective effect of calcitriol on $\beta$-cell function in recent-onset type 1 diabetes: the IMDIAB XIII trial," Diabetes Care, vol. 33, no. 9, pp. 1962-1963, 2010.

[114] X. Li, L. Liao, X. Yan et al., "Protective effects of 1- $\alpha$ hydroxyvitamin D3 on residual $\beta$-cell function in patients with adult-onset latent autoimmune diabetes (LADA)," Diabetes/Metabolism Research and Reviews, vol. 25, no. 5, pp. 411416, 2009.

[115] K. S. Aljabri, S. A. Bokhari, and M. J. Khan, "Glycemic changes after vitamin D supplementation in patients with type 1 diabetes mellitus and vitamin D deficiency," Annals of Saudi Medicine, vol. 30, no. 6, pp. 454-508, 2010.

[116] C. L. Wagner and F. R. Greer, "Prevention of rickets and vitamin D deficiency in infants, children, and adolescents," Pediatrics, vol. 122, no. 5, pp. 1142-1152, 2008.

[117] A. C. Ross, J. E. Manson, S. A. Abrams et al., "The 2011 report on dietary reference intakes for calcium and vitamin $\mathrm{D}$ from the Institute of Medicine: what clinicians need to know," Journal of Clinical Endocrinology and Metabolism, vol. 96, no. 1, pp. 53-58, 2011.

[118] S. Harris, "Can vitamin D supplementation in infancy prevent type 1 diabetes?” Nutrition Reviews, vol. 60, no. 4, pp. 118-121, 2002.

[119] M. Holick, N. Binkley, H. Bischoff-Ferrari et al., "Endocrine Society. Evaluation, treatment, and prevention of vitamin D deficiency: an Endocrine Society clinical practice guideline," The Journal of Clinical Endocrinology \& Metabolism, vol. 96, no. 7, pp. 1911-1930, 2011.

[120] G. Penna and L. Adorini, "1 $\alpha, 25$-dihydroxyvitamin D3 inhibits differentiation, maturation, activation, and survival of dendritic cells leading to impaired alloreactive T cell activation," Journal of Immunology, vol. 164, no. 5, pp. 2405-2411, 2000.

[121] L. Piemonti, P. Monti, M. Sironi et al., "Vitamin D3 affects differentiation, maturation, and function of human monocytederived dendritic cells," Journal of Immunology, vol. 164, no. 9, pp. 4443-4451, 2000. 


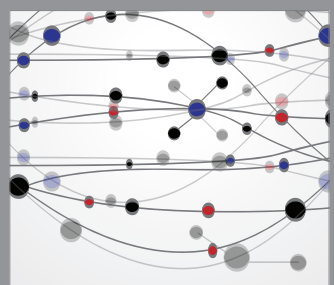

The Scientific World Journal
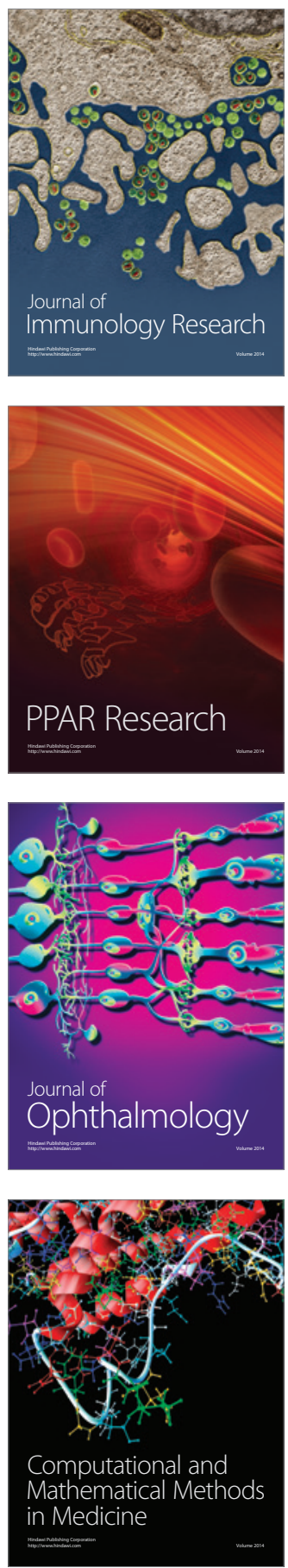

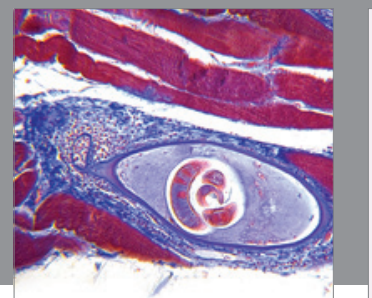

Gastroenterology

Research and Practice
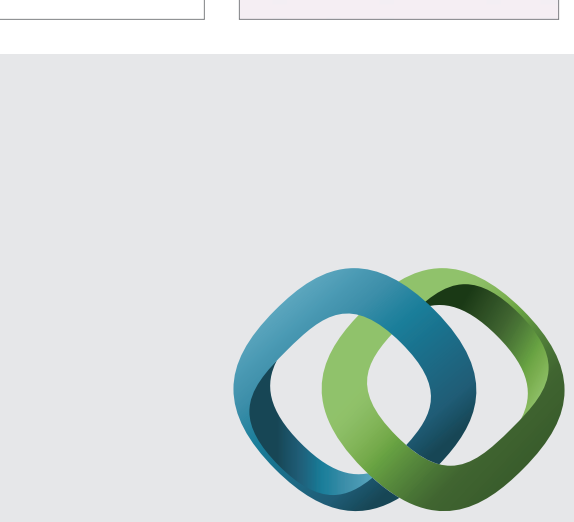

\section{Hindawi}

Submit your manuscripts at

http://www.hindawi.com
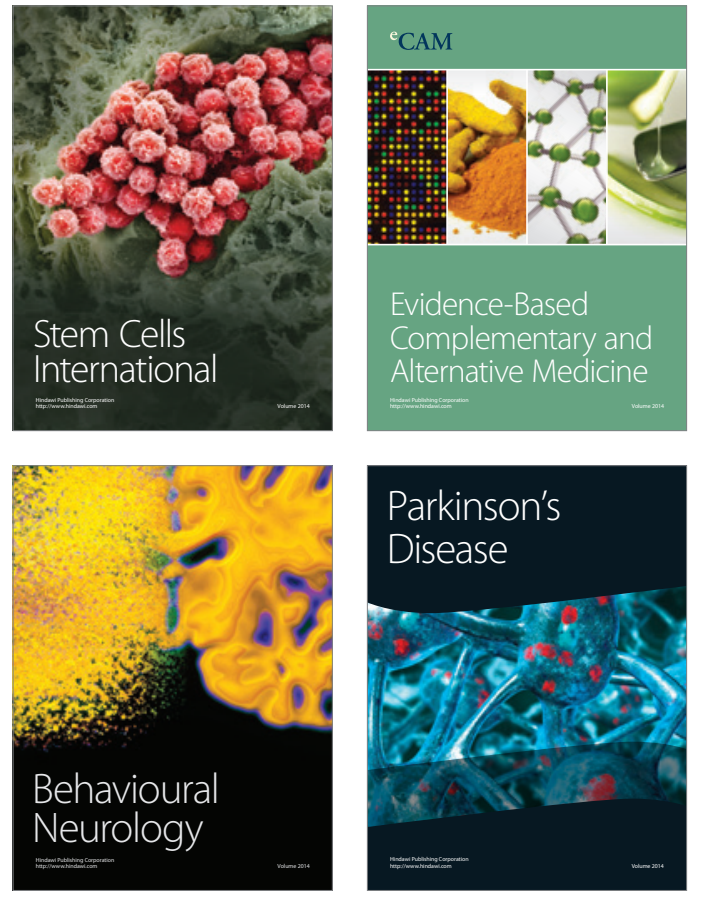
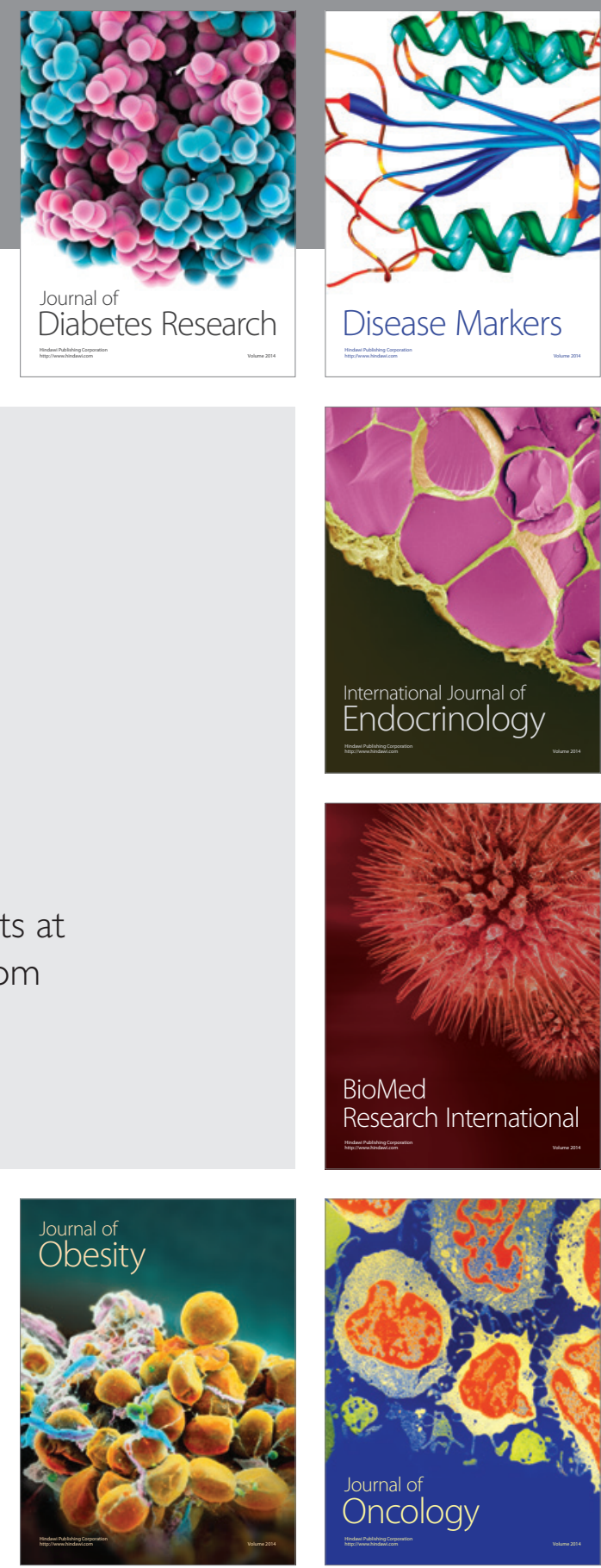

Disease Markers
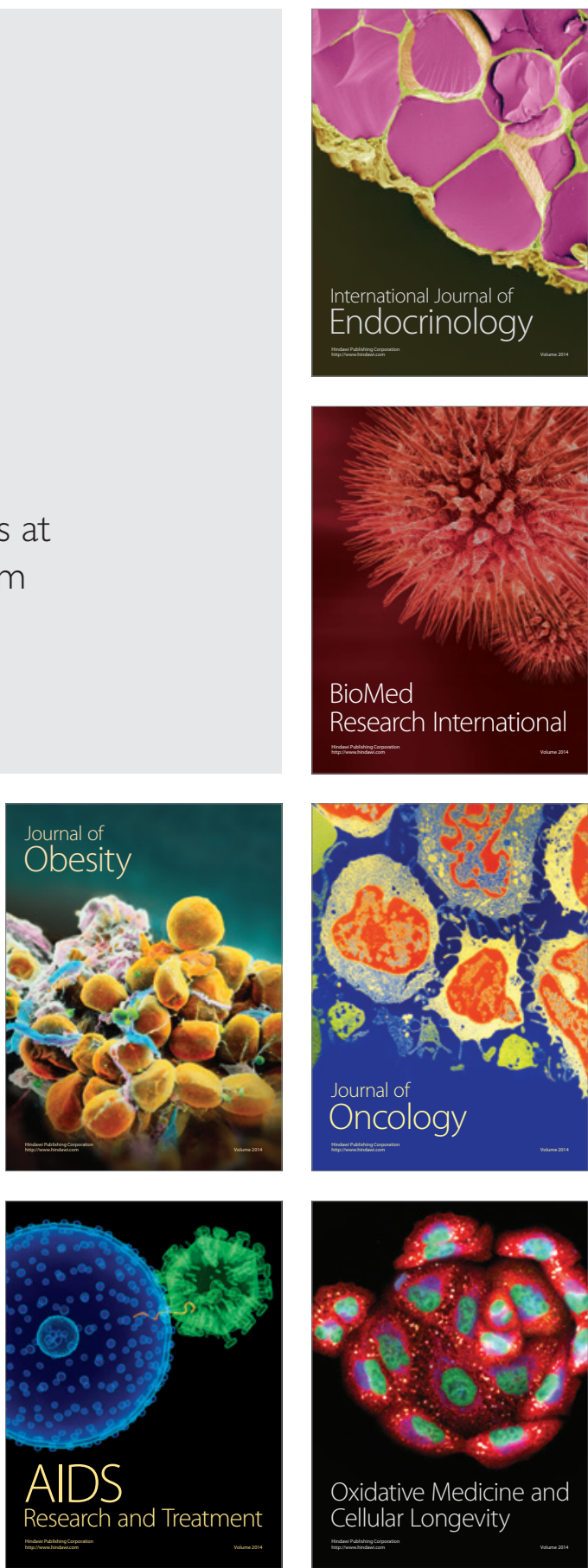